Journal of Advanced Research in Business and Management Studies

\title{
Identifying Relevant Predictor Variables for a Credit Scoring Model using Compromised-Analytic Hierarchy Process (Compromised-AHP)
}

\author{
Yosi Lizar Eddy ${ }^{1}$, Engku Muhammad Nazri2,*, Nor Idayu Mahat ${ }^{2}$ \\ Risk Quantification Section, Risk Management Department, Bank Muamalat Malaysia Berhad, 21 Jalan Melaka, 50100 Kuala Lumpur, Malaysia \\ School of Quantitative Sciences, Universiti Utara Malaysia, 06010 UUM Sintok, Kedah, Malaysia
}

\begin{abstract}
Developing an efficient credit scoring model to reduce the risk of personal-loan defaulters involves the selection of manageable reliable predictor variables in order to avoid the potential clients from providing too much information and to reduce the burden of a bank from keeping huge historical data, which can be burdensome and costly. The objective of this paper is therefore to illustrate how compromised-AHP can be used as one the methods to select such relevant reliable predictor variables before the final credit scoring model is constructed. A case study involving four experts from a bank was conducted. A set of sub-predictor variables under four main predictor variables namely financial indicators, demographic Indicators, employment indicators, and behavioural indicators was rated based on the perception of the four experts. The results reveal that, based on the experts' perception, the number of payments per year and payment interval, the loan or credit history, total income, total debt, the checking accounts, and age are the six most influential predictor variables while race, gender, and social status are the three least influential predictor variables.
\end{abstract}

Keywords:

Credit scoring model; predictor variables; loan defaulters; compromised-AHP

Copyright @ 2020 PENERBIT AKADEMIA BARU - All rights reserved

\section{Introduction}

The banking industry has developed into one of the comprehensive and competitive markets in contributing to economic development over the past few decades. One of its many businesses is providing personal loans to potential clients. Giving out personal loans is an insecure business but at the same time, it is one of the major sources of income to most banks. Banks would prefer not to allow credit to those customers who lack the capacity to pay back the credit given. Be that as it may, after some time, a certain percentage of the credits will eventually transform into bad loan regardless of the possibility that the banks tighten its credit policy [1-2]. Analysing the non-performing loans data will effectively measure the quality of credit endorsement process. The loan granting process must be observed vigilantly, and banks should formulate an effective credit risk management. After

\footnotetext{
* Corresponding author.

E-mail address: enazri@uum.edu.my
}

https://doi.org/10.37934/arbms.20.1.113 
all, many of the bad debts have been caused by the inappropriate conduct of approving new financing [2-4].

Currently the screening of whether a potential client's loan application should be approved or not is done through a credit scoring or credit risk model which is a decision analysis model with fundamental techniques to assist banks in deciding whether or not credit should be extended to an applicant of which will likely result in profits or losses [5-6]. The model is constructed through the utilization of various tools such as:

i. Statistical-based analyses such as linear regression [7], discriminant analysis [8-9], decision tree [10-13], and logistic regression [14-15,78].

ii. Artificial intelligence (Al)-based analyses such as genetic algorithm [16-20], simulated annealing [20-21], and neural network ([22-25,78]).

iii. Machine learning $[16,21,26]$.

However, despite the thorough process, the probability of the client-loan defaulters can still be high, thus raising a question of whether the existing credit scoring model used to screen such potential defaulters is still reliable. The reliability of the existing credit scoring model may be influenced by two factors, namely, the factors/variables used in the model and the weights assigned to those factors/variables [77].

The selection of the right predictor variables to be included in any credit scoring model of choice is crucial because there are many potential predictor variables discussed in the literature. Since credit scoring models are built up using factual data derived from historical recorded data of real clients [6] it is impossible for a bank to be asking its potential clients to furnish all the information for all the available predictor variables. Thus, selecting a set of suitable and manageable predictor variables must be done very carefully.

The objectives of this paper therefore are to identify the potential key predictor variables that can be included in a credit scoring model as discussed in the literature, and to illustrate how the final suitable and manageable set of predictor variables can be determined from the potential key predictor variables to be included in a credit scoring model of choice based on the experts' evaluations via Compromised-AHP.

Studies have shown that a bank's business success and even survival depend to a large extent on the ability of the bank management to construct and implement sound policies on credit risk. Many delinquency problems could have been avoided if the management can ensure that the earlier lending processes are conducted correctly of which failure to comply will lead to lower credit scores and high likelihood of non-payment [27-28]. Thus, reviewing the key variables that should be included in the credit scoring model will lead to a better screening process with the hope to see improvement on asset quality in terms of impaired asset position, better management of credit risk, improvement of turnaround time for new application, and cost saving [16], which in all will cumulatively contribute to the development of bank efficiency and profitability. In addition, Compromised-AHP was selected since it offers the same rigor of AHP which is the pairwise-comparison-type evaluation but without the worry of having inconsistent pairwise-comparison matrices which happens to be one of the major issues when applying AHP.

\section{Literature Review}

Two aspects that are relevant to the objectives of this paper are reviewed here. The two aspects are the potential predictor variables that can be included in a credit scoring model of choice, and the 
suitable techniques that can be used to shortlist the relevant predictor variables to a manageable set.

\subsection{Potential Predictor Variables to be Considered in a Credit Scoring Model}

As mentioned earlier, the objective of credit scoring is to estimate, by experimental way, the risk of giving out loan to specific criteria of borrowers. This objective can be attained with a decision model that enables a bank to forecast future repayment trend of a candidate with identical attributes to historical data of past applicants. Variables containing the information of the characteristics of borrowers are then applied into the credit scoring model $[2,29]$. It is therefore important to develop a credit scoring model which consists of the right predictor variables. According to Vojtek and Kocenda [30], the variables can be separated into four different indicators which are financial indicators, demographic indicators, employment indicators, and behavioral indicators.

\subsubsection{Financial Indicators}

Financial indicators involve the financial status or position of the loan applicant in repaying the loan [31]. The indicators include total gross income [32,33,53], total asset [33-34], total debt $[33,35.50,54,57]$, and collateral [36-37,51].

\subsubsection{Demographic Indicators}

Loan applicant's demographic indicators involve the characteristics of the applicant which among others cover age [38-39,47,48,50-54], marital status [2,47,50-52]), gender [2,47,50,54], race [2], number of dependents $[40-42,47,50,52,53]$, and social status $[43,52-54]$

\subsubsection{Employment Indicators}

Employment indicators cover the industry and nature of work that the applicant involved in together with the employment and unemployment benefit [44]. Some of the important indicator variables discussed in the literature are type of employer $[41,44,54,57]$, job position $[45,54,57]$, length of year in current employment $[43,46]$, and length of year in previous employment [2].

\subsubsection{Behavioural Indicators}

Potential client's behaviour is usually related to behaviour that is relevant to money management [31]. Thus, some of the potential indicator variables are the checking accounts $[43,54,56]$, the number of payments per year and payment intervals $[48,53,54,55,57])$, and the loan/credit history $[35,41$, 49,55].

\subsection{Techniques to Shortlist the Relevant Predictor Variables}

The primary objective in credit scoring is to develop an effective scoring model which contains only a set of manageable predictor variables. The total number of predictor variables cannot be too large in order to avoid the bank from keeping too many information and to reduce the complexity of the credit scoring model as well as the cost of collecting the information [58]. There are many techniques that can be utilized to select a set of manageable predictor variables from the pool of predictor variables found from the literature before the final scoring model is developed. 
For the case of identifying the suitable predictor variables for a credit scoring model, some of the more popular techniques are Elimination and Choice Expressing Reality (ELECTRE) [59-60], DEMATEL [61-62], Delphi method [63], and AHP [64-66]. Normally, the result will be in the form of the ranking scores of the predictor variables and in many instances the ranking as well as the scores differ from method to method [67]. Therefore, as the result may differ according to the model selected, it is relevant to establish the practical and managerial implications for selecting one model or the other [68].

\subsubsection{Analytic Hierarchy Process}

Analytic Hierarchy Process (AHP) is a technique that simplifies a complex problem by means of hierarchical analysis methodology, which enables subjective judgments among different predictor variables [69]. It has been used by various researchers and practitioners to build a credit risk assessment model [70-72]. Serrano-Cinca et al., [71] claimed that AHP can assess the credit history of the applicant (past), accounting information and intangible assets from the loan applicant itself from the financial (present), and from the social point of view (future).

Basically, the steps in AHP are as follows [73]:

Step 1: Defining the problem and the predictor variables to be used.

Step 2: Implementing pairwise comparisons for each pair of the predictor variables $(i, j)$ using a set of preference scale ranging from 1 to 9 as given in Table 1 and transfer those pairwise comparison values to a pairwise comparison matrix as shown immediately after Table 1.

Table 1

Preference scale for the AHP's pairwise comparisons

\begin{tabular}{lc}
\hline \hline Preference Level & Numeric Value \\
\hline Equally preferred & 1 \\
Equally to moderately preferred & 2 \\
Moderately preferred & 3 \\
Moderately to strongly preferred & 4 \\
Strongly preferred & 5 \\
Strongly to very strongly preferred & 6 \\
Very strongly preferred & 7 \\
Very strongly to extremely preferred & 8 \\
Extremely preferred & 9 \\
Note: When predictor variable $i$ compared to $j$ is assigned one of the above numbers, the predictor variable $j$ \\
compared to $i$ is assigned its reciprocal.
\end{tabular}

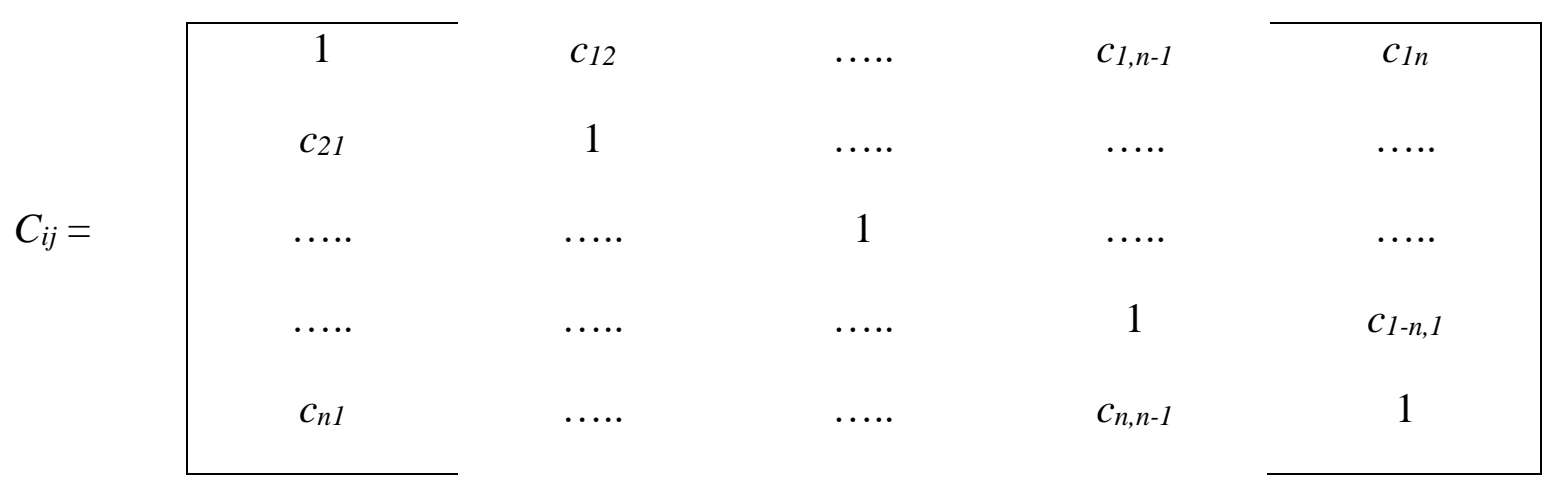

where $c_{i j}=$ pairwise comparison value between predictor variable $i$ and $j$. 
Step 3: Normalizing the pairwise comparison matrix by taking the column sum and dividing each value in the pairwise comparison matrix by its column sum.

Step 4: Computing the average of the values in each row of the pairwise comparison normalized matrix.

Step 5: Checking the consistency of the pairwise comparison matrix by calculating the consistency ratio ( $C R$-value) of the pairwise comparison matrix.

The $C R$-value can be calculated using formula 1:

$C R=C l / R I$

where $C l=$ consistency index $=(\lambda-n) /(n-1), \lambda=$ the largest pairwise comparison matrix's eigenvalue, $n=$ total number of predictor variables, and $R I=$ random index which can be determined by referring to the $R$ I-Table (Table 2).

Table 2

Random Index [69]

\begin{tabular}{lllcccccccccc}
$n$ & 1 & 2 & 3 & 4 & 5 & 6 & 7 & 8 & 9 & 10 & 11 & 12 \\
$R I$ & 0 & 0 & 0.58 & 0.9 & 1.12 & 1.24 & 1.32 & 1.41 & 1.45 & 1.49 & 1.51 & 1.56 \\
\hline
\end{tabular}

The pairwise comparisons must be repeated if the $C R$-value is bigger than 0.1. Otherwise, the pairwise comparison matrix is considered to be consistent, and the result obtained in step 4 will be the influence weight of each of the predictor variables in predicting loan-defaulters.

The possibility of getting an inconsistent pairwise comparison matrix is one of the main issues when dealing with AHP [74-75]. To tackle this inconsistency problem, [76] proposed a new Compromised-AHP technique which utilizes a Likert scale of 1 to 9 as a starting process.

\subsubsection{Compromised-AHP}

As mentioned earlier, Nazri et al., [76] introduced Compromised-AHP as a mean to tackle the inconsistent pairwise comparison matrix in AHP. The simple approach of utilizing a Likert scale of 1 to 9 guarantees that the desired pairwise comparison matrix will always be consistent. The approach begins by asking the evaluators to rate the level of influence of each predictor variable on the problem to be solved using the scale of 1 to 9 whereby 1 represents "least influential" while 9 represents "extremely influential". Next, the evaluation values will be transformed into Saaty's AHPpairwise comparison matrix $C=\left[c_{i j}\right]_{n \times n}$ through a simple process as follows: Suppose that the evaluator rated predictor variable $i$ as $w_{i}$ and predictor variable $j$ as $w_{j}$. Then $c_{i j}$ which is the pairwise comparison value between predictor variable $i$ and predictor variable $j$ and can be interpreted exactly as proposed by Saaty [69] in Table 1 is determined using formula 2 given below [76].

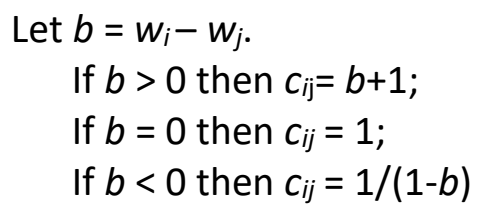

Having obtained the pairwise comparison matrix, the rest of the steps will be exactly the same as the standard AHP steps. 


\section{Applying Compromised-AHP on the Predictor Variables: Steps Taken and Results Obtained}

Applying Compromised-AHP [76], there are four steps involved towards identifying the manageable set of predictor variables. To illustrate the processes, a case study involving four senior expert officers from a bank in Malaysia was conducted. These four experts have had more than ten years of experience in dealing with the loan application approvals at the bank, thus justifying their inclusion for the evaluation of the predictor variables.

Step 1: Constructing the AHP-structure.

After a two-hour of brainstorming session, the four experts had agreed to consider all the predictor variables outlined in the literature review section in this study. As a result, the decision AHP-structure is as follows (Figure 1):

\begin{tabular}{|c|c|c|c|}
\hline \multicolumn{4}{|c|}{ Objective: To Select the Predictor Variables } \\
\hline \multicolumn{3}{|c|}{$\nabla$} & \\
\hline$\downarrow$ & $\downarrow$ & $\downarrow$ & $\downarrow$ \\
\hline Financial & Demographic & Employment & Behavioral \\
\hline$\nabla$ & $\downarrow$ & $\downarrow$ & $\nabla$ \\
\hline $\begin{array}{l}\text { - Total gross } \\
\text { income } \\
\text { - Total asset } \\
\text { - Total debt } \\
\text { - Collateral }\end{array}$ & $\begin{array}{l}\text { - Age } \\
\text { - Marital status } \\
\text { - Gender } \\
\text { - Race } \\
\text { - Number of } \\
\text { dependents } \\
\text { - Social status }\end{array}$ & $\begin{array}{l}\text { - Type of employer } \\
\text { - Job position } \\
\text { - Length of year in } \\
\text { current } \\
\text { employment } \\
\text { - Length of year in } \\
\text { previous } \\
\text { employment }\end{array}$ & $\begin{array}{l}\text { - The checking } \\
\text { accounts } \\
\text { - The number } \\
\text { of payments } \\
\text { per year and } \\
\text { payment } \\
\text { intervals } \\
\text { - The } \\
\text { loan/credit } \\
\text { history }\end{array}$ \\
\hline
\end{tabular}

Fig.1. The AHP-structure for the problem

Step 2: Designing the questionnaire and collecting the data.

The same four experts were asked to rate their perception on how influential each main predictor variable and each sub-predictor variable under each main predictor variable in predicting the probability of a loan defaulter. Each of the experts gave his/her rating via a set of questionnaires attached in the appendix.

Step 3: Constructing the pairwise comparison matrix via Compromised-AHP.

Before constructing the pairwise comparison matrix, the group evaluation score was calculated by taking the simple arithmetic mean score of all the experts' evaluation score as suggested by Lootsma [6]. To illustrate the approach, we give an example involving the evaluation by the experts for the main predictor variables.

Firstly, the average rating score for each main predictor variable is as given in Table 3. 


\section{Table 3}

The average rating score for the main predictor variables

\begin{tabular}{ccccc}
\hline Main Variable & Financial & Demographic & Employment & Behavioral \\
Mean Score & 7.75 & 6 & 6.50 & 8 \\
\hline
\end{tabular}

Next, applying formula (2), the pairwise comparison matrix $C_{\text {Main-ij }}$ for the main predictor variables was obtained.

Financial Demographic Employment Behavioral

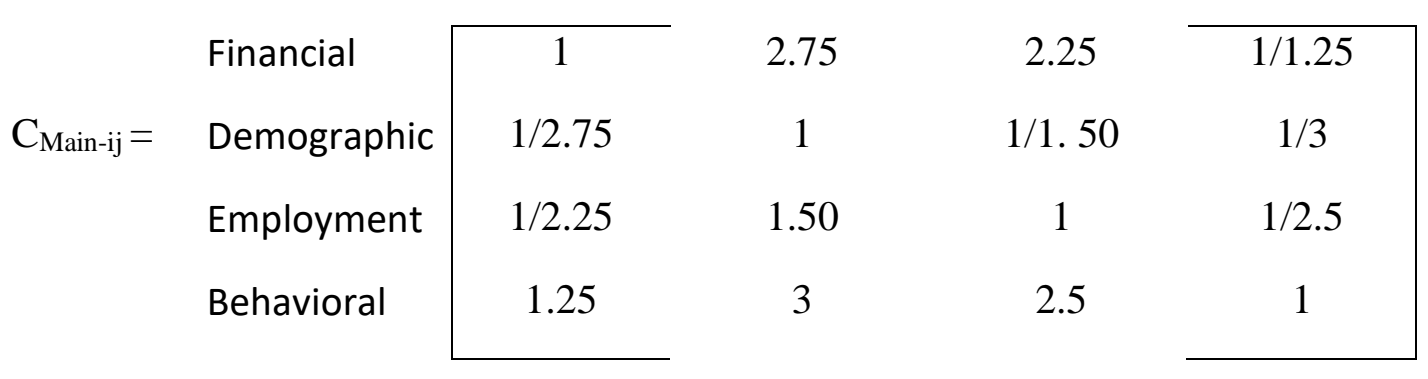

Step 4: Obtaining the final weight for each main predictor variable and sub-predictor variable under each main predictor variable.

The final weight that gives the level of influence each main predictor variable has on the probability of loan-defaulters based on the perception of the four experts was determined. The final weights are as given in Table 4. The $C R$-value obtained, i.e. $C R$-value $=0.00$, proves that the pairwise comparison matrix is consistent.

\section{Table 4}

The final weight for the main predictor variables

$\begin{array}{ccccc}\text { Main Variable } & \text { Financial } & \text { Demographic } & \text { Employment } & \text { Behavioral } \\ \text { Total Weight } & 0.332 & 0.119 & 0.160 & 0.389\end{array}$

CR-value $=0.00$

The results reveal that based on the perception of the four experts, behavioral indicators is the most influential main variable ( total weight $=38.9 \%$ ), followed by financial indicators (total weight $=$ $33.2 \%$ ), employment indicators (total weight $=16.0 \%$ ) and finally, demographic indicators (total weight $=11.9 \%)$.

The same procedure was performed for the sub-predictor variables under each main predictor variable. The average rating score and the final weight the sub-predictor variables under each main predictor variable are given in Table 5, Table 6, Table 7, and Table 8. The total real weight for each sub-predictor variable which can be used as the sub-predictor variable's overall influential ranking with respect to all the other sub-predictor variables under all the four main predictor variables was also calculated using formula 3.

Total real weight for sub-predictor $y$ under main predictor $z=$ (Total weight for sub-predictor $y) x$ (Total weight for main predictor $z$ ) 


\section{Table 5}

Mean score and final weight for the sub-predictor variables under "financial"

\begin{tabular}{|c|c|c|c|c|}
\hline Sub-Variable & Total gross income & Total asset & Total debt & Collateral \\
\hline Mean Score & 8.25 & 6 & 7.5 & 5.25 \\
\hline $\begin{array}{l}\text { Total Weight Under } \\
\text { Sub-Variable }\end{array}$ & 0.456 & 0.142 & 0.346 & 0.096 \\
\hline Total Real Weight & 0.151 & $\begin{array}{c}0.047 \\
C R \text {-value }=0.01\end{array}$ & 0.115 & 0.032 \\
\hline
\end{tabular}

Based on the perception of the four experts, total gross income is the most influential subpredictor variables under the main-predictor variable, financial, with a total weight of $45.6 \%$. This is followed by total debt (total weight $=34.6 \%$ ), total asset (total weight $=14.2 \%$ ), and collateral (total weight $=9.60 \%)$.

\section{Table 6}

Mean score and final weight for the sub-predictor variables under "demographic"

\begin{tabular}{|c|c|c|c|c|c|c|}
\hline Sub-Variable & Age & $\begin{array}{l}\text { Marital } \\
\text { status }\end{array}$ & Gender & Race & $\begin{array}{l}\text { Number of } \\
\text { dependents }\end{array}$ & Social status \\
\hline Mean Score & 7.25 & 6 & 3.5 & 2.5 & 5.75 & 4.25 \\
\hline \multicolumn{7}{|l|}{ Total Weight } \\
\hline $\begin{array}{c}\text { Under Sub- } \\
\text { Variable }\end{array}$ & 0.380 & 0.218 & 0.068 & 0.045 & 0.192 & 0.097 \\
\hline $\begin{array}{c}\text { Total Real } \\
\text { Weight }\end{array}$ & 0.045 & 0.026 & 0.008 & 0.005 & 0.023 & 0.011 \\
\hline & & & alue = & & & \\
\hline
\end{tabular}

Under the main-predictor variable demographic, the four experts are of the opinion that age is the most influential sub-predictor variable (total weight $=38.0 \%$ ) followed by marital status (total weight $=21.8 \%)$. Gender is believed to be the least influential sub-predictor variable with a total weight of $6.8 \%$.

\section{Table 7}

Mean score and final weight for the sub-predictor variables under "employment"

\begin{tabular}{|c|c|c|c|c|}
\hline Sub-Variable & $\begin{array}{c}\text { Type of } \\
\text { employer }\end{array}$ & Job position & $\begin{array}{c}\text { Length of year in } \\
\text { current } \\
\text { employment }\end{array}$ & $\begin{array}{c}\text { Length of year in } \\
\text { previous } \\
\text { employment }\end{array}$ \\
\hline Mean Score & 7.5 & 7.5 & 6.75 & 5.25 \\
\hline Total Weight & & & & \\
\hline $\begin{array}{l}\text { Under Sub- } \\
\text { Variable }\end{array}$ & 0.344 & 0.344 & 0.213 & 0.099 \\
\hline Total Real Weight & 0.055 & $\begin{array}{c}0.055 \\
\text { CR-value }=0.00\end{array}$ & 0.034 & 0.016 \\
\hline
\end{tabular}

Type of employer and job position are perceived as equally most influential sub-indicator variables with a total weight of $34.4 \%$ each, followed by length of year in current employment (total weight $=21.3 \%$ ) and length of year in previous employment (total weight $=9.9 \%$ ). 


\section{Table 8}

Mean score and final weight for the sub-predictor variables under "behavioral"

\begin{tabular}{|c|c|c|c|}
\hline Sub-Variable & $\begin{array}{l}\text { The checking } \\
\text { accounts }\end{array}$ & $\begin{array}{l}\text { The number of } \\
\text { payments per year } \\
\text { and payment } \\
\text { intervals }\end{array}$ & The loan/credit history \\
\hline Mean Score & 7.25 & 8 & 8 \\
\hline $\begin{array}{c}\text { Total Weight Under Sub- } \\
\text { Variable }\end{array}$ & 0.222 & 0.389 & 0.389 \\
\hline Total Real Weight & 0.086 & 0.151 & 0.151 \\
\hline
\end{tabular}

Finally, under the main predictor variable behavioral, the four experts believed that the number of payments per year and payment intervals as well as the loan/credit history will influence the probability of the personal-loan defaulters the most with a total weight of $38.9 \%$ each. The checking account came in third (total weight $=22.2 \%$ ).

\section{Discussion and Conclusion}

This paper presented a case study involving four experts from a bank in determining which predictor variables should be taken into consideration for the revision of an existing credit scoring model involving personal loan future clients. Compromised-AHP was utilized to determine the level of influence each predictor variable has on the probability of the personal loan defaulters. Based on the influential rating done by the four experts and the real total weights obtained, the number of payments per year and payment interval (real total weight $=15.1 \%$ ), the loan or credit history (real total weight $=15.1 \%)$, total income (real total weight $=15.1 \%)$, total debt (real total weight $=11.5 \%)$, the checking accounts (real total weight $=8.64 \%$ ), and age (real total weight $=4.52 \%$ ) are the six most influential predictor variables. These six predictor variables contribute to $69.96 \%$ of the total weight $100 \%$. Meanwhile, the four experts perceived race $(0.53 \%)$, gender $(0.809 \%)$, and social status $(0.97 \%)$ as the three least influential predictor variables. With such ranking, the bank can now decide how many of these variables to be included in the new credit scoring model.

Based on the results of this study, two suggestions can be put forward on how a bank can implement its credit scoring model:

i. Continue with the existing credit scoring model while concurrently, start to require new potential clients to furnish the information pertaining to the additional new predictor variables that have not been included in the existing credit scoring model. Once enough information is gathered, the new credit scoring model can be developed and utilized.

ii. Contact all the existing clients to request for the needed new information and develop the new credit scoring model to be implemented as soon as possible.

This study is by no means, perfect. Firstly, not all the variables have been included in this study. Variables such as loan amount and history of relationship with the bank for example, were not considered. Thus, future studies should include such variables to be considered. Secondly, some of the predictor variables might correlate with each other. Neither compromised-AHP nor AHP would be able to detect the correlation among predictor variables. Thus, it would be interesting to see the outcome of this study had another approach that could detect some level of correlation among predictor variables is applied. One such technique is DEMATEL. 


\section{References}

[1] Jayadev, M., and N. Padma. "Wilful defaulters of Indian banks: A first cut analysis." IIMB Management Review (2019).

https://doi.org/10.1016/j.iimb.2019.10.005

[2] Samreen, Asia, and Farheen Batul Zaidi. "Design and development of credit scoring model for the commercial banks of Pakistan: Forecasting creditworthiness of individual borrowers." International Journal of Business and Social Science 3, no. 17 (2012).

[3] De Bock, Reinout, and Mr Alexander Demyanets. Bank asset quality in emerging markets: Determinants and spillovers. No. 12-71. International Monetary Fund, 2012. https://doi.org/10.5089/9781475502237.001

[4] Abd Karim, Mohd Zaini, Sok-Gee Chan, and Sallahudin Hassan. "Bank efficiency and non-performing loans: Evidence from Malaysia and Singapore." Prague Economic Papers 2, no. 1 (2010). https://doi.org/10.18267/i.pep.367

[5] Calin, A. C. and O. C. Popovici. O. C. "Modeling credit risk through credit scoring." Internal auditing and risk management 34 no. 1 (2014): 105-116.

[6] Lahsasna, Adel, Raja Noor Ainon, and Ying Wah Teh. "Credit Scoring Models Using Soft Computing Methods: A Survey." Int. Arab J. Inf. Technol. 7, no. 2 (2010): 115-123.

[7] Bansal, Gaurav, Atish P. Sinha, and Huimin Zhao. "Tuning data mining methods for cost-sensitive regression: a study in loan charge-off forecasting." Journal of Management Information Systems 25, no. 3 (2008): 315-336. https://doi.org/10.2753/MIS0742-1222250309

[8] Poulsen, John, and Aaron French. "Discriminant function analysis." San Francisco State University: San Francisco, CA (2008).

[9] Blanco, Antonio, Rafael Pino-Mejías, Juan Lara, and Salvador Rayo. "Credit scoring models for the microfinance industry using neural networks: Evidence from Peru." Expert Systems with applications 40, no. 1 (2013): $356-364$. https://doi.org/10.1016/j.eswa.2012.07.051

[10] Bastos, Joao. "Credit scoring with boosted decision trees." (2007).

[11] Mandala, I. Gusti Ngurah Narindra, Catharina Badra Nawangpalupi, and Fransiscus Rian Praktikto. "Assessing credit risk: An application of data mining in a rural bank." Procedia Economics and Finance 4 (2012): 406-412. https://doi.org/10.1016/S2212-5671(12)00355-3

[12] Wozabal, David, and Ronald Hochreiter. "A coupled Markov chain approach to credit risk modeling." Journal of Economic Dynamics and Control 36, no. 3 (2012): 403-415. https://doi.org/10.1016/i.jedc.2011.09.011

[13] Siu, Tak-Kuen, Wai-Ki Ching, S. Eric Fung, and Michael K. Ngף. "On a multivariate Markov chain model for credit risk measurement." Quantitative Finance 5, no. 6 (2005): 543-556. https://doi.org/10.1080/14697680500383714

[14] Chen, Keqin, Kun Zhu, Yixin Meng, Amit Yadav, and Asif Khan. "Mixed Credit Scoring Model of Logistic Regression and Evidence Weight in the Background of Big Data." In International Conference on Intelligent Systems Design and Applications, pp. 435-443. Springer, Cham, 2018. https://doi.org/10.1007/978-3-030-16657-1 40

[15] Sohn, So Young, Dong Ha Kim, and Jin Hee Yoon. "Technology credit scoring model with fuzzy logistic regression." Applied Soft Computing 43 (2016): 150-158.

https://doi.org/10.1016/i.asoc.2016.02.025

[16] Munkhdalai, Lkhagvadorj, Tsendsuren Munkhdalai, Oyun-Erdene Namsrai, Jong Yun Lee, and Keun Ho Ryu. "An empirical comparison of machine-learning methods on bank client credit assessments." Sustainability 11, no. 3 (2019): 699.

https://doi.org/10.3390/su11030699

[17] Correa, Alehandro, Andres Gonzalez, and Camilo Ladino. "Genetic algorithm optimization for selecting the best architecture of a multi-layer perceptron neural network: a credit scoring case." In SAS Global Forum. 2011.

[18] SHUAI, Li, L. I. Tingting, X. U. Chao, and Z. H. O. U. Zongfang. "Applied Research of Genetic Algorithm in Personal Credit Risk Combined Assessment." Management Science and Engineering 7, no. 3 (2013): 81-85.

[19] Oreski, Stjepan, and Goran Oreski. "Genetic algorithm-based heuristic for feature selection in credit risk assessment." Expert systems with applications 41, no. 4 (2014): 2052-2064. https://doi.org/10.1016/j.eswa.2013.09.004

[20] Bluhm, Christian, Ludger Overbeck, and Christoph Wagner. Introduction to credit risk modeling. Crc Press, 2016. https://doi.org/10.1201/9781584889939 
[21] Zhu, You, Chi Xie, Gang-Jin Wang, and Xin-Guo Yan. "Predicting China's SME credit risk in supply chain finance based on machine learning methods." Entropy 18, no. 5 (2016): 195.

https://doi.org/10.3390/e18050195

[22] Dželihodžić, Adnan, Dženana Đonko, and Jasmin Kevrić. "Improved Credit Scoring Model Based on Bagging Neural Network." International Journal of Information Technology \& Decision Making 17, no. 06 (2018): 1725-1741. https://doi.org/10.1142/S0219622018500293

[23] Bekhet, Hussain Ali, and Shorouq Fathi Kamel Eletter. "Credit risk assessment model for Jordanian commercial banks: Neural scoring approach." Review of Development Finance 4, no. 1 (2014): 20-28. https://doi.org/10.1016/i.rdf.2014.03.002

[24] Alabi, M. A., S. Issa, and R. B. Afolayan. "An application of artificial intelligent neural network and discriminant analyses on credit scoring." Math Theory Model 3, no. 11 (2013): 20-28.

[25] Eletter, Shorouq Fathi, Saad Ghaleb Yaseen, and Ghaleb Awad Elrefae. "Neuro-based artificial intelligence model for loan decisions." American Journal of Economics and Business Administration 2, no. 1 (2010): 27. https://doi.org/10.3844/ajebasp.2010.27.34

[26] Kruppa, Jochen, Alexandra Schwarz, Gerhard Arminger, and Andreas Ziegler. "Consumer credit risk: Individual probability estimates using machine learning." Expert Systems with Applications 40, no. 13 (2013): 5125-5131. https://doi.org/10.1016/i.eswa.2013.03.019

[27] Odonkor, Alexander Ayertey. "An Assessment of Credit Risk Management Practices of Adansi Rural Bank Limited." International Journal of Economics and Finance 10, no. 11 (2018): 110-110. https://doi.org/10.5539/ijef.v10n11p110

[28] Akwaa Sekyi, Ellis Kofi, and Jordi Moreno Gené. "Internal controls and credit risk relationship among banks in Europe." Intangible Capital, 2017, vol. 13, num. 1, p. 25-50 (2017). https://doi.org/10.3926/ic.911

[29] Siddiqi, Naeem. Credit risk scorecards: developing and implementing intelligent credit scoring. Vol. 3. John Wiley \& Sons, 2012. https://doi.org/10.1002/9781119201731

[30] Vojtek, Martin, and Evžen Koèenda. "Credit-scoring methods." Czech Journal of Economics and Finance (Finance a uver) 56, no. 3-4 (2006): 152-167.

[31] Mudzingiri, Calvin, John W. Muteba Mwamba, and Jacobus Nicolaas Keyser. "Financial behavior, confidence, risk preferences and financial literacy of university students." Cogent Economics \& Finance 6, no. 1 (2018): 1512366. https://doi.org/10.1080/23322039.2018.1512366

[32] Fred, P. B. "Accessing micro credit, borrowers' characteristic and household income in rural areas: case of kasese." Unpublished master's thesis). University of Makerere, Kampala, Uganda (2009).

[33] Hanić, Aida, Emina Žunić, and Adnan Dželihodžić. "Scoring Models of Bank Credit Policy Management." Economic analysis 46, no. 1-2 (2013): 12-27.

[34] Kahn, Amos, and Mike Ward. "The impact of collections strategy on the profitability of unsecured bank microloans." Studies in Economics and Econometrics 32, no. 3 (2008): 1-19.

[35] Edwards, Sue. In too deep: CAB clients' experience of debt. London: Citizens Advice, 2003.

[36] Kaniovski, Yuri M., and G. Ch Pflug. "Risk assessment for credit portfolios: a coupled Markov chain model." Journal of Banking \& Finance 31, no. 8 (2007): 2303-2323. https://doi.org/10.1016/i.jbankfin.2007.02.005

[37] Nadali, Ahmad, Sanaz Pourdarab, and Hamid Eslami Nosratabadi. "Class Labeling of Bank Credit's Customers Using AHP and SAW for Credit Scoring with Data Mining Algorithms." International Journal of Computer Theory and Engineering 4, no. 3 (2012): 401. https://doi.org/10.7763/IJCTE.2012.V4.492

[38] Gärling, Tommy, Erich Kirchler, Alan Lewis, and Fred Van Raaij. "Psychology, financial decision making, and financial crises." Psychological Science in the Public Interest 10, no. 1 (2009): 1-47. https://doi.org/10.1177/1529100610378437

[39] Perry, Vanessa G., and Marlene D. Morris. "Who is in control? The role of self-perception, knowledge, and income in explaining consumer financial behavior." Journal of consumer affairs 39, no. 2 (2005): 299-313. https://doi.org/10.1111/i.1745-6606.2005.00016.x

[40] Abdou, Hussein A. "Genetic programming for credit scoring: The case of Egyptian public sector banks." Expert systems with applications 36, no. 9 (2009): 11402-11417. https://doi.org/10.1016/i.eswa.2009.01.076

[41] Sundarasen, S. D. D., M. S. Rahman, N. Rajangam, and R. Sellappan. “Cradle to grave.” Financial literacy programs and money management 6 no. 6 (2014): 240-246. https://doi.org/10.5539/ijef.v6n6p240 
[42] Zuccaro, Cataldo. "Classification and prediction in customer scoring." Journal of Modelling in Management (2010). https://doi.org/10.1108/17465661011026158

[43] Mpofu, Thabiso Peter, and Macdonald Mukosera. "Credit scoring techniques: a survey." International Journal of Science and Research (IJSR) (2014): 2319-7064.

[44] Gutiérrez-Nieto, Begoña, Carlos Serrano-Cinca, and Juan Camón-Cala. "A credit score system for socially responsible lending." Journal of Business Ethics 133, no. 4 (2016): 691-701. https://doi.org/10.1007/s10551-014-2448-5

[45] Eddy, Y. L. and E. M. N, Engku Abu Bakar. "Credit scoring models: techniques and issues." Journal of advanced research in business and management studies 7 no. 2 (2017): 29-41.

[46] Leonard, Kevin J. "The development of credit scoring quality measures for consumer credit applications." International Journal of Quality \& Reliability Management (1995). https://doi.org/10.1108/02656719510087346

[47] Folefack, Achille Jean Jaza, and Josephine Sandrine Mahbou Teguia. "Factors influencing loan repayment by credit beneficiaries of microfinance institutions in the Far North region, Cameroon." Russian Journal of Agricultural and Socio-Economic Sciences 51, no. 3 (2016). https://doi.org/10.1108/02656719510087346

[48] Murthy, Uma, and Paul Anthony Mariadas. "An exploratory study on the factors contributing loan repayment default among the loan borrowers in micro finance institutions in Shah Alam, Selangor." International Journal of Business and Management 12, no. 12 (2017): 242-250. https://doi.org/10.5539/ijbm.v12n12p242

[49] Gaston, Ellen, and Mr Inwon Song. Supervisory roles in loan loss provisioning in countries implementing IFRS. No. 14-170. International Monetary Fund, 2014. https://doi.org/10.5089/9781484381120.001

[50] Muthoni, Muturi Phyllis. "Assessing Borrower's and Business' Factors Causing Microcredit Default in Kenya: A Comparative Analysis of Microfinance Institutions and Financial Intermediaries." Journal of Education and Practice 7, no. 12 (2016): 97-118.

[51] Mensah, George Yaw. "Determination of Some Factors that Influences Loan Default Payment: Case Study: Customers from Akatakyiman Rural Bank Ltd Komenda." PhD diss., 2012.

[52] Gutu, Fikadu, Wondaferahu Mulugeta, and Belay Birlie. "Determinant Factors Affecting Loan Repayment Performance of Women Borrowers from Micro Finance Institutions in Southwest Ethiopia: Evidence from Four Woredas around Gilgel Gibe Hydroelectric Power Dam." Global Journal of Management And Business Research (2017).

[53] Melese, Mikir, and Milkessa Asfaw. "Research Article Determinants of Loan Repayment Performance of Omo Microfinance Institution: In the Case of Mizan Aman Town, Southwest Ethiopia."

[54] Fatollahi, Ahmad, and Ebrahim Samani. "Factors contributing to repayment behaviour of microloans in Agricultural Bank of Meshkinshahr." International Finance and Banking 2, no. 1 (2015): 27-37. https://doi.org/10.5296/ifb.v2i1.7748

[55] Perry, Vanessa G., and Marlene D. Morris. "Who is in control? The role of self-perception, knowledge, and income in explaining consumer financial behavior." Journal of consumer affairs 39, no. 2 (2005): 299-313. https://doi.org/10.1111/i.1745-6606.2005.00016.x

[56] Valins, Oliver. When debt becomes a problem: A literature Study. Wellington, New Zealand: Ministry of Social Development, 2004.

[57] Chugh, Ms Gargi, and Veena Tewari. "A study on behavioral factors influencing consumer debt in the sultanate of Oman."

[58] Viganò, Laura. "A credit scoring model for development banks: An African case study/un modele de" credit scoring" pour les banques de developpement: une etude de cas Africain." Savings and development (1993): 441-482.

[59] Doumpos, Michalis, and José Rui Figueira. "A multicriteria outranking approach for modeling corporate credit ratings: An application of the Electre Tri-nC method." Omega 82 (2019): 166-180. https://doi.org/10.1016/j.omega.2018.01.003

[60] Chavira, Diego Alonso Gastelum, Juan Carlos Leyva Lopez, Jesus Jaime Solano Noriega, Omar Ahumada Valenzuela, and Pavel Anselmo Alvarez Carrillo. "A credit ranking model for a parafinancial company based on the ELECTRE-III method and a multiobjective evolutionary algorithm." Applied Soft Computing 60 (2017): 190-201. https://doi.org/10.1016/i.asoc.2017.06.021

[61] Tsai, Sang-Bing, Guodong Li, Chia-Huei Wu, Yuxiang Zheng, and Jiangtao Wang. "An empirical research on evaluating banks' credit assessment of corporate customers." SpringerPlus 5, no. 1 (2016): 2088. https://doi.org/10.1186/s40064-016-3774-0 
[62] De, Gejirifu, Zhongfu Tan, Menglu Li, Lilin Huang, Qiang Wang, and Huanhuan Li. "A credit risk evaluation based on intuitionistic fuzzy set theory for the sustainable development of electricity retailing companies in China." Energy Science \& Engineering 7, no. 6 (2019): 2825-2841.

https://doi.org/10.1002/ese3.464

[63] Ershadi, M. J., and D. Omidzadeh. "Customer validation using hybrid logistic regression and credit scoring model: a case study." Calitatea 19, no. 167 (2018): 59-62.

[64] Alinejad, E., A. H. Sajedi, A. Ziaee, and M. A. Seyedin. "Credit scoring models of customers in banks." Singaporean journal of business economics and management studies 1 no. 7 (2013): 37-41.

https://doi.org/10.12816/0003767

[65] Ferreira, Fernando AF, Sérgio P. Santos, and Vítor MC Dias. "An AHP-based approach to credit risk evaluation of mortgage loans." International Journal of Strategic Property Management 18, no. 1 (2014): 38-55.

https://doi.org/10.3846/1648715X.2013.863812

[66] Xu, Lin, and Yong Zhang. "A Credit Rating Model for Online P2P Lending Based on Analytic Hierarchy Process." In Proceedings of the Tenth International Conference on Management Science and Engineering Management, pp. 537-549. Springer, Singapore, 2017.

https://doi.org/10.1007/978-981-10-1837-4 46

[67] El Amine, Mehdi, Jérôme Pailhes, and Nicolas Perry. "Critical review of multi-criteria decision aid methods in conceptual design phases: application to the development of a solar collector structure." Procedia CIRP 21 (2014): 497-502.

https://doi.org/10.1016/i.procir.2014.03.134

[68] Dehe, Benjamin, and David Bamford. "Development, test and comparison of two Multiple Criteria Decision Analysis (MCDA) models: A case of healthcare infrastructure location." Expert Systems with Applications 42, no. 19 (2015): 6717-6727.

https://doi.org/10.1016/i.eswa.2015.04.059

[69] Saaty, T.L. "The analytic hierarchy process." McGraw-Hill, 1980. https://doi.org/10.21236/ADA214804

[70] Turan, Hakan. "The Weighting of Factors Affecting Credit Risk in Banking." Procedia Economics and Finance 38 (2016): 49-53.

https://doi.org/10.1016/S2212-5671(16)30175-7

[71] Serrano-Cinca, Carlos, and Begoña Gutiérrez-Nieto. "A decision support system for financial and social investment." Applied Economics 45, no. 28 (2013): 4060-4070.

https://doi.org/10.1080/00036846.2012.748180

[72] Bhattarai, Shashi, and Shivjee Roy Yadav. "AHP application in banking: unfolding utility in a situation of financial crisis." In Proceedings of International Symposium on Analytic Hierarchy Process, Pittsburgh, PA, USA. 2009.

[73] Dellen, D. The final frontier for evidence-based management and optimal decision making. Pearson Education, Inc. 2019.

[74] Kazibudzki, Paul Thaddeus. "An examination of performance relations among selected consistency measures for simulated pairwise judgments." Annals of Operations Research 244, no. 2 (2016): 525-544.

https://doi.org/10.1007/s10479-016-2131-6

[75] Emrouznejad, Ali, and Marianna Marra. "The state of the art development of AHP (1979-2017): a literature review with a social network analysis." International Journal of Production Research 55, no. 22 (2017): 6653-6675. https://doi.org/10.1080/00207543.2017.1334976

[76] Nazri, E. M., M. Balhuwaisl, and M. M. Kasim. "A pre-evaluation step towards a guaranteed consistent AHP-based pairwise comparison." Journal of Advanced Research in Social and Behavioural Sciences 4, no. 1 (2016): 73-80.

[77] Abdou, Hussein A., and John Pointon. "Credit scoring, statistical techniques and evaluation criteria: a review of the literature." Intelligent systems in accounting, finance and management 18, no. 2-3 (2011): 59-88. https://doi.org/10.1002/isaf.325

[78] Munkhdalai, Lkhagvadorj, Jong Yun Lee, and Keun Ho Ryu. "A Hybrid Credit Scoring Model Using Neural Networks and Logistic Regression." In Advances in Intelligent Information Hiding and Multimedia Signal Processing, pp. 251 258. Springer, Singapore, 2020.

https://doi.org/10.1007/978-981-13-9714-1 27 